\title{
A Study on Housing Price in Klang Valley, Malaysia
}

\author{
Paul Anthony Mariadas ${ }^{1}$, Mahiswaran Selvanathan ${ }^{2}$, Tan Kok Hong ${ }^{1}$ \\ ${ }^{1}$ SEGi University, Malaysia \\ ${ }^{2} \mathrm{PhD}$, SEGi University, Malaysia \\ Correspondence: Paul Anthony Mariadas, SEGi University, Malaysia. E-mail: paulanthonydas@ segi.edu.my
}

Received: September 26, 2016

Accepted: November 8, 2016

Online Published: November 9, 2016

doi:10.5539/ibr.v9n12p103

URL: http://dx.doi.org/10.5539/ibr.v9n12p103

\begin{abstract}
The main aim of this study is to measure the factors influencing housing price in Klang Valley, Malaysia. This paper examines empirically whether the increasing trend in the Malaysian housing price is associated to changes in the population, construction cost, housing speculation, and inflation rate. The paper is exploratory in nature. The data is collected via questionnaire survey form distributed to youngest respondents in the sample area which is Klang Valley region. Each single elements are calculated its average index respect to few level of influence under respondents opinion. The index will then treated as influencing level of the factors. The paper delivers empirical outcomes that the population, construction cost and housing speculation are the main factors of housing prices. However, fluctuations in housing prices could not necessarily be influenced by the inflation rate. The overall result of this paper strongly recommends that housing price in the Malaysian residential property market is increasing continuously. Therefore, efforts to control the hike in housing price is needed by government and policy controllers in order to maintain the affordable to own a house in Malaysia.
\end{abstract}

Keywords: housing price-population, housing price-construction cost, housing price-housing speculation and Price inflation.

\section{Introduction}

Housing plays a very important role in our life. Housing is an important fix asset for the people as well as a basic need for the citizen. Nowadays the housing price in Malaysia is much higher compare to last time. The higher price gives a huge problem for the low income group in the developing country (alaghbari, 2008). The government also has implemented some policies and programs such as PRIMA (1Malaysian People's Housing Programme), First Home Scheme and PPA1M (1Malaysian Civil Servant Housing Programme) to ensure that Malaysians have a chance to obtain a place to stay. In Malaysia, the development of housing project is carried by the two main sectors, private and public sectors. Besides that, government of Malaysia also has established set of housing policy which focuses on the housing delivery and production which have the involvement of private sector, especially in housing scheme development (Ong, 2013).

In the recent years, Malaysian economics have grown rapidly and this lead to the increase of the residential housing's demand among the city areas in Malaysia. Due to the demand, the price of housing at cities is increasing. In the past few years, market of residential house in Malaysia has experienced a significant price expansion throughout Malaysia especially in Klang Valley. There are also many housing projects around the urban areas in Klang Valley nowadays. The housing price is continuously increasing in Malaysia but the average of the Malaysian household income is not increase in same level. In 2013 the average monthly income is only RM3686 (Zheng, 2014). So the majority of citizen in Malaysia are worry about increasing of high housing price. According to the data of Valuation and Property Services Department (JPPH, 2015, housing price has increased about $45 \%$ in the past 10 years.

The Malaysian housing price index increases yearly. In 1990s, the Malaysian housing price index was around 100 annually, but in 2010, the housing price index has increased in a big margin to around 275 annually. According to the (NAPIC 2013), the Malaysian transaction on housing property was increasing from the year 2007 till year 2012. In 2007 the transaction was around 500 million and increased to 1500 million in 2012. The increase of transaction is not only for the residential property, it is also involves of industry and development property. According to the Malaysian Deputy Finance Minister (2011), the Malaysia's average housing price is increasing up to $20 \%$ each year after the economic recession in 2007. Most of the people are wondering that such 
high annual increase in housing price will lead them to face unaffordability to own a house (Ong, 2013). For example, before 2008, people can buy a terrace house around Kuala Lumpur at RM 250,000 to RM 450,000. But after 2008, the price had already gone up. In 2012, a terrace house around Kuala Lumpur areas cost around RM 500,000 to RM 900,000. This shows the transaction of houses increase the property trading. Once the market is active, it leads to the increase the housing price. It shows that the housing price increasing rapidly compare to last 10 years and it lead to become a common problem that face by all the Malaysian citizen. This price hike affects the society and standard of living, it also showing an unhealthy growing of Malaysian economy. So it is important to find out the factors that lead to this problem and state the relationship between the factors and the problems.

\section{Research Objective}

2.1 To Determine the Relationship between Population and Housing Price in Klang Valley, Malaysia.

2.2 To Determine the Relationship between Construction Cost and Housing Price in Klang Valley, Malaysia.

2.3 To Determine the Relationship between Housing Speculation and Housing Price in Klang Valley, Malaysia.

2.4 To Determine the Relationship between Inflation Rate and Housing Price in Klang Valley, Malaysia.

\section{Literature Review}

\subsection{Housing Price}

Housing price has become one of the main focuses for the past 10 years' time in Malaysia. According to Chen (2000), people in Malaysia needed a total of 8,850,554 houses. Therefore, 3,581,643 units of new housing have to build within the next ten years. But there are only 1,790,820 units were built in these ten years. So, the change of policy is needed to face the population growth (Chen, 2000). According to Anand (2015), median range of house price in Kuala Lumpur was stated around RM 490, 000 to RM 555, 000. This is nearly 5.4 times compared to other main cities in Malaysia. Due to the policy of the Malaysian government to recover of Malaysian economic, encourage the foreign investment in the housing market. The demand of the housing in the market has been increase but the supply in Malaysia unable to fulfill the market demand. Therefore, housing price in Malaysia is expected to be increased due to the imbalance of demand and supply (Levin, 1997).

\subsection{Population}

Total population is called a universe (Barakova, 2003). In today's world, the population in Malaysia is rapidly increasing. The citizen required more houses to stay, but in Malaysia the production of houses is slow due to many regulation, law and also procedures on development of houses. According to Vemeulen and Van Ommeran (2006), "people will move to another area where houses are built, but the houses are not necessarily built in the area where people would want to live". The main reason of buying houses in this area is due to the working place, cheaper rental and convenience and facilities. Better facilities and environment which attract more people move to this area will lead to increasing of housing price. In the economy sector, although there are a lot of other factors that led to increase the housing prices, but growth of the population might be one of the significant factor (Mulder, 2006). Fast urbanization is perhaps an exclusive factor driving the housing market in one country. The increasing of the urban population during the past ten years due to the fast urbanization led to the change of the household structure (Hou, 2010). Urbanization in Malaysia is expanding rapidly, the total amount of urban centers which have population of 10,000 and above in Malaysia have increase 11 percent each year. 70 percent of the Malaysian total population is living in the city and become an urban society (Hassan, 2009). In the period 1995-2005, there is 68.8 per cent of internal migration in Malaysia. Due to the rapid transformation into an urban society, the demand for the housing in the cities is continuously increasing. The number of children and teenager also increase and eventually lead to future housing issues when they grow older, the need for the housing will be increased as well. The rapid increasing of the population leads to the increasing on housing demand in the market in the future. 


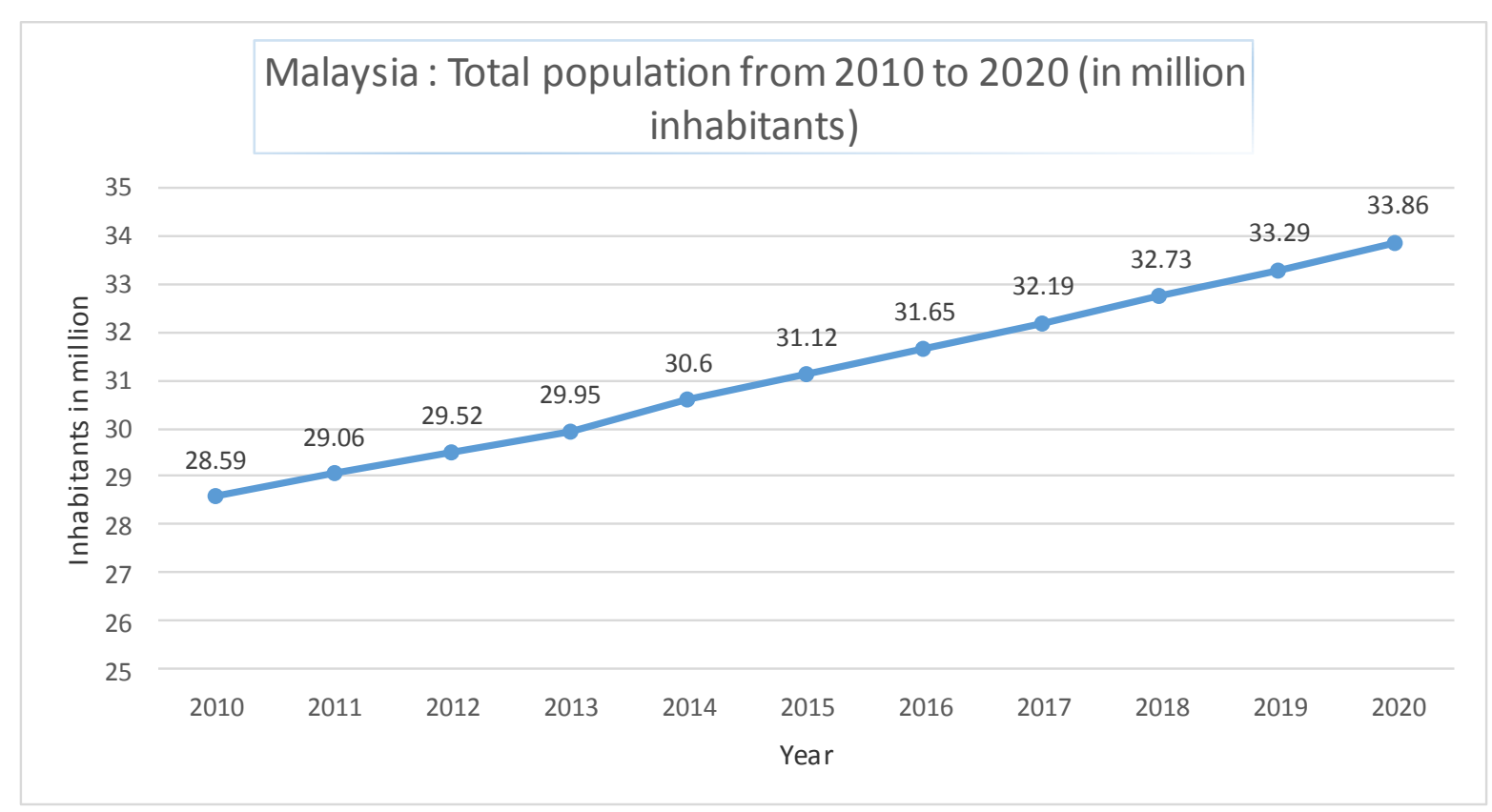

Figure 1. Population of Malaysia

Sources from (Statistics Malaysia, 2015)

\subsection{Construction Cost}

Construction cost defines as the expenses that involved such as contractor for labor, material, equipment in developing of houses (Kassim, 2005). According to the Haron (2005), the cost of construction will be one of the important subject in the project of housing development and it is led the project to success or failure. The cost of construction can be define as resource of the project planning, budgeting cost, cost estimating, and cost of control on the material cost, labor, machinery, technology, and cost of transportation (Mohammed, 2003). In the construction project, cost of material is one of the highest financial load. Due to the increasing in the cost of material, the developer will not bear the cost due to increasing in material but transfer the cost to buyer by increasing the housing price (Ibrahim, 2012). The labor cost also included in the construction cost that involved in a development project. The construction sector in Malaysia is affected by the shortage of skilled labor force. Working in a construction side is hard compare to other work and it needed more physical energy, so that the Malaysian citizen are less involved in it, and the developers need to depend on the foreign labor who are willing to earn less but do more in work. The Malaysia constructor required more labor from foreign country to fulfill the requirement of general construction working with the lower payment compare to the local labor. Hence, during the shortage the improvement of wages and the benefits for winning labor force, identical with high rate of development (Sambasivan, 2007).

\subsection{Housing Speculation}

Housing speculation is the action of financial transaction, or trading of an asset, which have a significant risk of losing or all of the initial outlay, in expectation of substantial gain. Malaysia has listed as the tops Asian country to invest in, said by The Global Property Guide. Malaysia has a mix of the relatively low round-trip purchases costs, high rental yields and low capital gain taxes which will be very attractive for the investor to invest in the property market (Mohammad, 2010). A Consumer Trends Survey which done by the Malaysian property website (IProperty.com.my, 2010) which shows that Malaysian investors are more likely to invest in the high end properties. Due to the positive speculation on the housing, it will lead to increase in housing price, increase in vacancies, increase in mortgage rate, and increase in the residential investment. It is the change of the expectation about the future house price by homeowners and housing investor. The intuition behind the restriction on the housing price is that the prospect of being able to sell the house at higher price in the future so it leads to higher price now. The speculation in housing market can be a group of treats speculation as a deviation from a model benchmark. According to Glaeser (2012), easy credit cannot explain the full extent of the housing boom and this leave door open for a potentially important role of irrational expectations (Towbin, 2014). In the financial market, the relationship between housing price and speculation is injurious to the public because they heighten price fluctuations. It creates a rapid increase of housing price and it may create speculation of housing 
price boom or bubble. The investor will speculate property prices because of the rapid growth of housing price. However, the speculation is qualified through the number of confirmer transaction as the transaction will be increased itself from time to time. Active speculation in the market will direct increase the price of housing in the area due to the expectation of the investor in this market (Larsen, 2010). But it will also lead to price boom and bubble in this area. Malaysia is one of the most active market in the Asian country.

\subsection{Inflation Rate}

Inflation is defined as the price for services and goods is increasing continuously and the purchasing power of currency is decreasing. Central banks are the main party who playing an important role to control the inflation, and avoid deflation. During the inflation, price for good and services will be increased. Due to this, the material of the construction will be increased as well. When the money supply increase, it will cause the house price increase and it already note by the global scenario (Ong, 2013). The government tended to react to this by imposing strong austerity policies and macro-economic controls, which often led to economic depression afterward. The high inflation will have a serious impact to the developers and state-owned enterprises who are the dominant buyer of commodity housing. Inflation will affect the housing price through the increasing of the cost of construction. Comparing the price of new and old houses, the new houses will be more expensive on average than the older. Next is the impact on rent, when the rent fee increase, it will lead to increasing of the housing price because the price of the house is equal to the present value of future streams of actual or imputed rents. Thus, inflation impact house prices through increase of the rents.

\subsection{Research Framework}

The dependent variable of this study is the housing price while the independent variables of this study are the population, construction cost, housing speculation, and inflation rate.

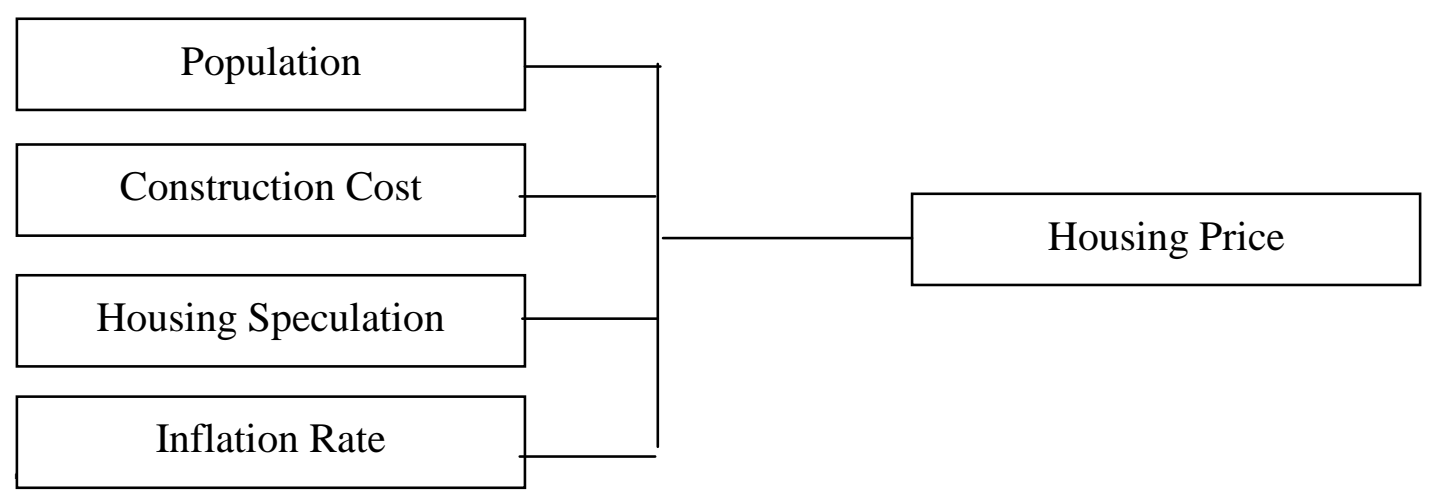

Figure 2. Research Framework

\section{Method}

This study is an exploratory in nature with a quantitative approach. The data is collected via questionnaire survey form distributed to 120 youngest respondents in the sample area which is Klang Valley region. Each single elements are calculated its average index respect to few level of influence under respondents opinion. The index will then treated as influencing level of the factors. These data were later analyzed using Statistical Package for Social Science (SPSS) version 21.0.

\section{Analysis and Interpretation}

This aim of this study is to investigate the most significant factors that influence the housing price among youngest in Klang Valley, Malaysia. The factors which have chosen to examine for this study is population, construction cost, housing speculation, and inflation rate. The relationship between housing price and the four factors were analysed in chapter four.

\subsection{Correlation Analysis}

Housing price shows an average correlation with population, construction cost, and housing speculation. While housing price shows a very low correlation with inflation rate. Population shows a moderate correlation with housing price, construction cost, and housing speculation. While population show a very low correlation with inflation rate. Construction cost has a moderate correlation with housing price, and population. Correlation between construction cost with housing speculation, and inflation rate is low. Housing speculation has a moderate correlation with housing price, and population. The correlation between housing speculation with construction cost, and inflation rate is low. Lastly, inflation rate has a very low correlation with housing price, 
and population. A low correlation exists with construction cost, and housing speculation.

Table 1. Correlation Analysis

\begin{tabular}{|c|c|c|c|c|c|c|}
\hline \multicolumn{7}{|c|}{ Correlations } \\
\hline & & Housing price & Population & $\begin{array}{c}\text { Construction } \\
\text { cost }\end{array}$ & $\begin{array}{l}\text { Housing } \\
\text { speculation }\end{array}$ & Inflation rate \\
\hline \multirow[t]{3}{*}{ Housing price } & Pearson Correlation & 1 & $.491^{* *}$ & $.468^{* * *}$ & $.400^{* * *}$ & .099 \\
\hline & Sig. (2-tailed) & & .000 & .000 & .000 & .283 \\
\hline & $\mathrm{N}$ & 120 & 120 & 120 & 120 & 120 \\
\hline \multirow[t]{3}{*}{ Population } & Pearson Correlation & $.491^{* *}$ & 1 & $.361^{* * *}$ & $.460^{* * *}$ & .051 \\
\hline & Sig. (2-tailed) & .000 & & .000 & .000 & .582 \\
\hline & $\mathrm{N}$ & 120 & 120 & 120 & 120 & 120 \\
\hline \multirow[t]{3}{*}{ Construction cost } & Pearson Correlation & $.468^{* *}$ & $.361^{* *}$ & 1 & $.292^{* *}$ & $.210^{*}$ \\
\hline & Sig. (2-tailed) & .000 & .000 & & .001 & .021 \\
\hline & $\mathrm{N}$ & 120 & 120 & 120 & 120 & 120 \\
\hline \multirow[t]{3}{*}{ Housing speculation } & Pearson Correlation & $.400^{* *}$ & $.460^{* *}$ & $.292^{* * *}$ & 1 & .135 \\
\hline & Sig. (2-tailed) & .000 & .000 & .001 & & .141 \\
\hline & $\mathrm{N}$ & 120 & 120 & 120 & 120 & 120 \\
\hline \multirow[t]{3}{*}{ Inflation rate } & Pearson Correlation & .099 & .051 & $.210^{*}$ & .135 & 120 \\
\hline & Sig. (2-tailed) & .283 & .582 & .021 & .141 & \\
\hline & $\mathrm{N}$ & 120 & 120 & 120 & 120 & 120 \\
\hline
\end{tabular}

**. Correlation is significant at the 0.01 level (2-tailed).

*. Correlation is significant at the 0.05 level (2-tailed).

\subsection{Multiple Regression Analysis}

$36.1 \%$ of the dependent variable (housing price among youngest) can be explained by the four independent variables (population, construction cost, housing speculation, and inflation rate) in this study. The following $63.9 \%$ of the dependent variable is explained by other independent variable which are not been examine in this study. The arrangement of strengths among the independent variable (population, construction cost, housing speculation, and inflation rate) that contributes to the dependent variable housing price) are population $(\mathrm{B}=.300)$, construction cost $(\mathrm{B}=.310)$, housing speculation $(\mathrm{B}=.172)$, and inflation rate $(\mathrm{B}=-.005)$. For each of the variable, the significant value will show whether these variable contributed significantly to the equation. The hypothesis will be accepted if the value of significant is less than .05 .

Table 2. Multiple Regression Analysis

\begin{tabular}{ccccc}
\hline Dependent Variable & $\begin{array}{c}\text { Independent } \\
\text { Variable }\end{array}$ & $\begin{array}{c}\text { Coefficient Value } \\
(\mathbf{B})\end{array}$ & $\begin{array}{c}\text { Significant Value } \\
(\text { Sig) }\end{array}$ & $\mathbf{R}^{2}$ \\
\hline \multirow{3}{*}{ Housing Price } & Population & .300 & .001 & .000 \\
& Construction Cost & .310 & .047 & .361 \\
& Housing Speculation & .172 & .951 & \\
\hline
\end{tabular}

\subsection{Hypotheses Result}

Table 3. Hypotheses Result

\begin{tabular}{lc}
\hline \multicolumn{1}{c}{ Hypothesis } & Results \\
\hline H1: There is a positive relationship between the populations and the housing price in Klang & Accepted \\
Valley, Malaysia. & Accepted \\
H2: There is a positive relationship between the construction costs and the housing price in & Accepted \\
Klang Valley, Malaysia. & Rejected \\
H3: There is a positive relationship between the housing speculation and the housing price in & \\
Klang Valley, Malaysia. & \\
Klang Valley, Malaysia. &
\end{tabular}

\section{Overall Finding Based on the Research Objectives}

The aim of this study is to investigate the most significant factors that influence the housing price among youngest in Klang Valley, Malaysia. The factors which have chosen to examine for this study is population, construction cost, housing speculation, and inflation rate. The relationship between housing price and the four factors was analysed in chapter four.

\subsection{To Determine the Relationship between Population and Housing Price in Klang Valley, Malaysia}

The relationship between population and housing price is positively related. There are few researches which states that, population had positive relationship with housing price. According to Mulder (2006) population is the 
main key factor which affecting the housing price, people will move to the area houses are built or the area which more convenience or have more people living in. According to Hassan (2009) 70\% people live in city and it shows population is one of the factors that influencing living area, thus it will lead to effect of housing price. Besides that Hou (2010) states that increase of the population leads to the expanding of urban area. Indirectly this will lead to the increase of housing price.

\subsection{To Determine the Relationship between Construction Cost and Housing Price in Klang Valley, Malaysia}

The construction cost positively related with housing price. According to Kassim (2005) construction cost has direct influence on the housing price due to the raw material. The price hike in raw material will increase the housing price. According to Haron (2005) construction cost will be included into the developers' account when they develop any housing projects. According to Ibrahim (2012) construction cost is the production cost of housing development and it will increase the selling price of a house.

\subsection{To Determine the Relationship between Housing Speculation and Housing Price in Klang Valley, Malaysia}

There is a positive relationship between housing speculation and housing price. According to Mohammad (2010) the more the speculation of the product, the market more active and attract more investor to invest on the product. Thus this will lead to an increase on demand. According to Towbin (2014) there is a relationship between house price and speculation in financial market and speculation is injurious to public because it improves price fluctuations in the market.

\subsection{To Determine the Relationship between Inflation Rate and Housing Price in Klang Valley, Malaysia}

This study shows inflation rate is not influence the housing price. The result is different from Ong (2013) which saying inflation will load real payment on the long-term fixed-rate mortgage, increasing of money supply lead to inflation and reduce in money value and lead to increasing of housing price. This supported by Anari (2002) by saying that inflation rate have a relation between house price, rent, and also consumer price index. Although in this study, inflation rate had been rejected due to some reason, but there are seen to have relationship in other studies.

\section{Conclusion}

Results showed that population, construction costs and housing speculation are influence the housing price in Malaysia. Therefore, efforts to increase the affordability should be continued by the Government of Malaysian, policy maker, developer and other related parties in order to the youngest able to buy a house. The effort would further upgrade and maintain the affordability as well as assist in achieving the dream to own a house in Malaysia.

\section{References}

Alaghbari, W. E., Salim, A., Dola, K., \& Abdullah, A. A. A. (2012). Identification of significant factors influencing housing cost in Yemen. International Journal of Housing Markets and Analysis, 5(1), 41-52. http://dx.doi.org/10.1108/17538271211206653

Anand, R. (2015). Malaysia's home prices 'seriously unaffordable', says Khazanah Research. The Malaysia Insider.

Anari, A., \& Kolari, J. (2002). House prices and inflation. Real Estate Economics, 30(1), 67-84. http://dx.doi.org/10.1111/1540-6229.00030

Barakova, I., Bostic, R. W., Calem, P. S., \& Wachter, S. M. (2003). Does credit quality matter for homeownership? Journal of housing Economics, 12(4), 318-336. http://dx.doi.org/10.1016/j.jhe.2003.09.002

Chen, E. L. L. (2000). An overview of the Malaysian property market. In UPM Workshop: Environment Friendly Township for Developing Countries. Serdang, Malaysia: UPM Press.

Statistics Malaysia. (2015). Department of Statistics Malaysia.

Glaeser, E. L., \& Nathanson, C. G. (2014). Housing bubbles (No. w20426). National Bureau of Economic Research.

Haron, N. A., Hassim, I. S., Kadir, M. R. A., \& Jaafar, M. S. (2005). Building cost comparison between conventional and formwork system: a case study of four-storey school buildings in Malaysia. American Journal of Applied Sciences, 2(4), 819-823. http://dx.doi.org/10.3844/ajassp.2005.819.823

Hassan, N. (2009). Issues and challenges of sustainable urban development in Malaysia. Sustainable urban development issues in Malaysia, 1-22. 
Hou, Y. (2010). Housing price bubbles in Beijing and Shanghai? A multi-indicator analysis. International Journal of Housing Markets and Analysis, 3(1), 17-37. http://dx.doi.org/10.1108/17538271011027050

Ibrahim, M., Faizah, A., \& Norazriyati, W. (2012). Exploiting town planning factors in land development: Case stude of urban housing in Kuala Lumpur, Malaysia. Journal of Facilities Management, 307-317.

JPPH. (2015). Retrieved from www.jpph.gov.my

Kassim, A. (2005). Cross-border movement of foreign workers in Malaysia: a comparative analysis. Master Builders Journal 3rd Quarter, 79-91.

Larsen, J. E. (2010). The impact of buyer-type on house price: Some evidence from the USA. International Journal of Housing Markets and Analysis, 3(1), 60-68. http://dx.doi.org/10.1108/17538271011027087

Levin, E. J., \& Wright, R. E. (1997). The impact of speculation on house prices in the United Kingdom. Economic modelling, 14(4), 567-585. http://dx.doi.org/10.1016/S0264-9993(97)00008-4

Mohammad, T. (2010). the need for accepting Wakaf (waqf) assets in Malaysian property market. Sustaining the means of sustainability.

Mohamad, R. (2003). The need for systematic project management in construction industry. Malaysia: Macroworks.

Mulder, C. H. (2006). Population and housing: A two sided relationship. Demographic Research, 15, 401-412. http://dx.doi.org/10.4054/DemRes.2006.15.13

Ong, T. S. (2013). Factors affecting the price of housing in Malaysia. Journal of Emerging Issues in Economics, Finance and Banking, 1(5), 414-429.

Sambasivan, M., \& Soon, Y. W. (2007). Causes and effects of delays in Malaysian construction industry. International Journal of project management, 25(5), 517-526. http://dx.doi.org/10.1016/j.ijproman.2006.11.007

Towbin, P. P., \& Weber, S. (2014). Speculation and the US housing boom. In Housing markets and the macroeconomy: challenges for monetary policy and financial stability conference, Eltvile, Bundesbank.

Zheng, D. (2014). Information Engineering and Education Science. In D. Zheng, Business \& Economics (p. 376). Tianjin, China.

\section{Copyrights}

Copyright for this article is retained by the author(s), with first publication rights granted to the journal.

This is an open-access article distributed under the terms and conditions of the Creative Commons Attribution license (http://creativecommons.org/licenses/by/4.0/). 